\title{
The Railroad And An Iowa \\ Editor: A Case Study*
}

Donovan L. Hofsommer

IN EARLY JANUARY, 1866, a representative of the firm of Edgington and Brothers made his way to the newly opened offices of the Eldora Ledger. The Edgington concern operated a daily stage line between Iowa Falls and Marshalltown and it wished to advertise its services in the next and subsequent issues of the Ledger. The Edgington stages were scheduled to "Leave Marshalltown everyday on the arrival of the train from the East, arriving at Iowa Falls on the same day. [The stages from Iowa Falls were to depart] everyday at 2 o'clock A.M., arriving at Marshalltown in time for the trains going East." The route from Iowa Falls was designed to serve the villages of Berlin, Steamboat Rock, Xenia, Eldora, Union, Norris, Albion and Marietta before making the connection with the Cedar Rapids and Missouri River Railroad (predecessor of the Chicago and North Western System). Eldora residents were pleased to have the common carrier services afforded them by the Edgington Company, but not unlike other Midwestern communities of the post-Civil War period, they wanted a railroad! The Eldora fight to secure rail transportation exemplifies the same struggle in dozens of other communities in Iowa, and thus serves as an excellent case study of the inventiveness with which local journalists approached this problem.

The development of Chicago as a commercial and transportation center and the passage of the Pacific Railroad Act

'The writer wishes to thank Dr. Leland L. Sage of the University of Northern Iowa and Dr. Odie B. Faulk of Oklahoma State University for their assistance in the writing of this article.

${ }^{1}$ Eldora Ledger, January 10, 1866. 
of 1862 combined to signal the early completion of a series of east-west railroads across the state of Iowa. Virtually every village and hamlet in the southern two-thirds of Iowa counties earnestly aspired and generally expected to be located on one of the competing roads. Eldorans watched the various construction projects with mixed emotions. The Dubuque and Sioux City Company would pass to the north at Ackley, while the next horizontal road to the south had already been completed from Clinton to Boone. ${ }^{2}$ The distance intervening between the two roads was little more than thirty miles; Eldora was in the middle, and it was generally agreed that this hopeful Hardin County community had not been and would not be favored by one of the major horizontal lines. Disappointed but not disillusioned, enterprising Eldora leaders began to study the merits of an alternative-the creation of a northsouth railroad-designed, of course, to service both central Iowa and themselves. Among those who recognized the importance of such a railroad, a man who labored diligently for its development, not just as a local carrier but also as an integral part of a north-south artery, was R. H. McBride, editor and publisher of the Eldora Ledger.

Like many Iowa newspapers of the day, McBride's Ledger was consistently euphoric about the railroad industry: "The successful development of the vast resources of this State, and its subsequent prosperity and wealth, are largely dependent upon the facilities offered by railroad communication. To encourage and foster our railroad enterprises by every feasible means, is manifestly the part of wisdom." ${ }^{3}$ While Eldora was still a transportation frontier, ignored by contenders for transcontinental routes, McBride turned his attention to the possible advantages afforded by a mid-Iowa rail link with St. Louis. The Iowa editor said: "the importance of a railway connection with St. Louis by which the products of the Des Moines, Iowa, and Cedar Valleys will find a cheap and readier market, than eastern lines are able to afford, is being duly comprehended in enterprising circles."4 Moreover, the east-west lines repre-

${ }^{2}$ Yesterday and Today: A History of the Chicago and North Western Railway System (Chicago: n.p., 1910) this is the third edition of a company history., p. 40.

${ }^{3}$ Eldora Ledger, January 16, $1866 . \quad{ }^{4} I b i d$. 


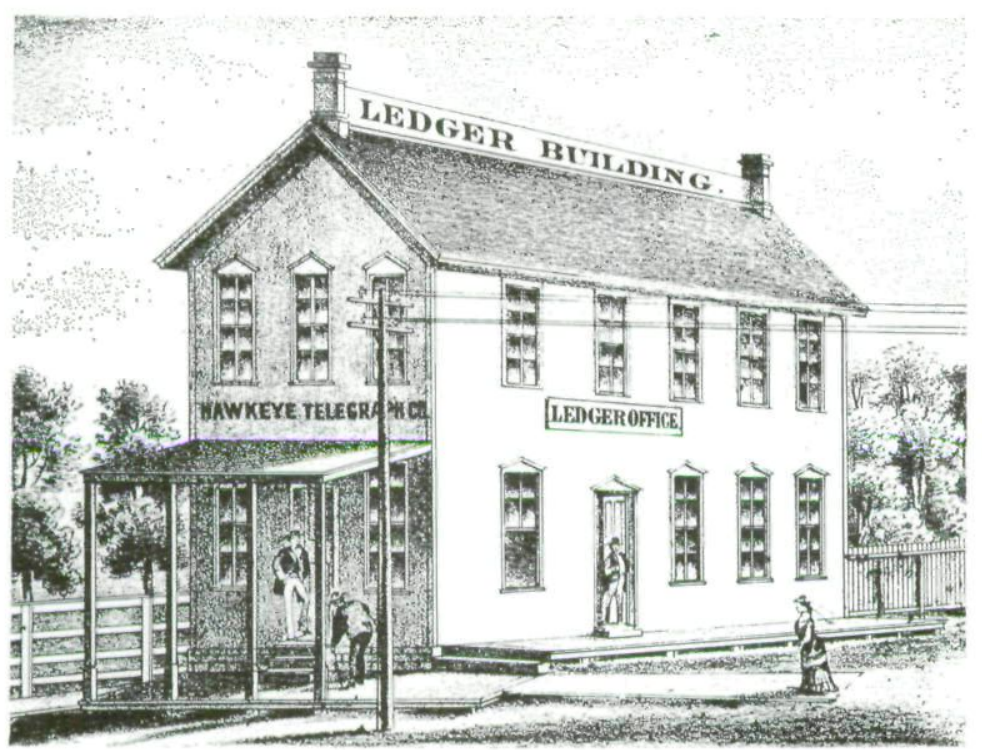

Courtesy of D. L. Hofsommer

Ledger Building, Eldora, lowa

sented Chicago's economic imperialism, and much like Chicago merchants, Chicago railroads had an "immoderate thirst for monopolization," pressed "exhorbitant charges," and were "enemies to . . . agricultural prosperity."

The advantages of a St. Louis gateway included yearround navigation to the ocean, although it was necessary to transload cargo at both St. Louis and New Orleans. It was generally believed by Iowans living in the mid-section of the state that combined rail-water transportation via St. Louis would bring a savings to shippers and at the same time force the redoubtable Chicagoans into a more competitive posture. And was it not logical to assume that the major growing cities of America's heartland should be linked by north-south railways? McBride allowed that it was logical indeed! He reminded his readers that "Iowa occupies a central position, a pivotal point between the Atlantic and Pacific coasts" ${ }^{\prime \prime}$ and was naturally located to reap the benefits of multiple routings, be they east-west or north-south. Specifically, McBride favored a line of road that would move up the Cedar Valley to

${ }^{5} \mathrm{Ibid}$.

${ }^{6}$ Ibid. 
an eventual connection with St. Paul, for such a road "would bring [Eldora] in more direct and certain connection with the pine regions of the North." a route that would miss his residence by more than twenty-five miles is unclear; however, in 1866 the projected Iowa Central Railroad, running from Cedar Falls to the Missouri state line (via Toledo and Oskaloosa), appeared to be "a sure thing." Completion of the Iowa Central Road would forge a major link in connecting a Minnesota concern with a Missouri company and would thus create a St. Paul-St. Louis bridge line. ${ }^{8}$

It was the nearby presence of coal that changed McBride's mind. The discovery of gold particles some seasons earlier had greatly excited the populace along the Iowa River in Hardin County; that flurry was short-lived, but in the search for precious metal, prospectors had found that the river valley just north of Eldora was laced with veins of bituminous coal. This coal supply proved to be the single most important commodity in terms of finally delivering the steam car to Eldora.

As early as 1857 Captain Gustavus W. Smith had made a survey from Dubuque to Sioux City, noting the quality of soil and minerals between the two points. Smith had found the veins of coal in the Iowa valley to be approximately four to four-and-one-half feet thick and the quality moderately good. ${ }^{9}$ Dr. C. A. White, the State Geologist, generally had corroborated Smith's estimates while pointing out that the value of the mineral was greatly enhanced because it was so situated that the fuel-starved areas of the north and west could be easily served-provided that transportation could be arranged. For local needs the coal banks offered outcroppings which allowed anyone to take what he needed. However, as the surrounding area became increasingly populated, the demand for Hardin County coal had grown to the point where it became profitable to exploit the resource commercial-

${ }^{7}$ Ibid.

${ }^{8}$ See Luella M. Wright, Peter Melendy (Iowa City: The State Historical Society, 1943), pp. 220-248, and Donovan L. Hofsommer, "A History of the Iowa Central Railway," (unpublished Master's Thesis, University of Northern Iowa, Cedar Falls, 1966), pp. 8-19.

${ }^{9}$ History of Hardin County, Iowa (Springfield, Illinois: Union Publishing Company, 1883), p. 343. 


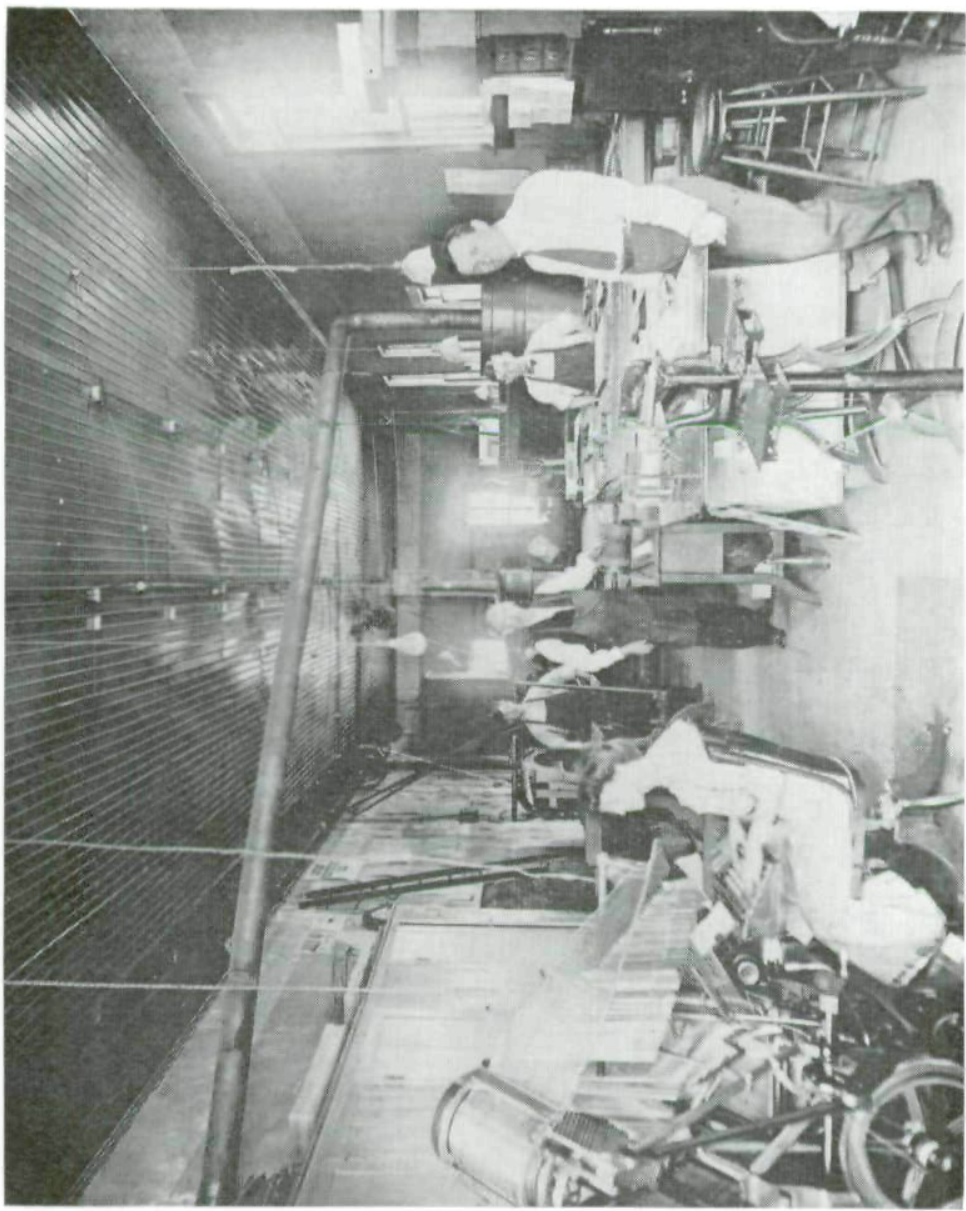

Plant and Office of the Eldora Ledger (date unknown)

Conrtesy of D. L. Hofsommer

ly. Soon S. A. Moran, the first producer, was joined by others, and marketed coal as far away as Cedar Rapids, Waverly, and Independence. ${ }^{10}$

In spite of the fact that the existence of coal in the Iowa River valley was widely recognized, the major railroads continued to ignore Eldora. To the south the Cedar Rapids and Missouri River Railroad was heavily engaged in its race to be the first eastern connection with the Union Pacific, and ob-

${ }^{10}$ Ibid., p. 639. 
viously had little time or enthusiasm for the construction of a "stub" line to tap the Eldora coal banks. To the north, the Dubuque and Sioux City Line had recovered from its Civil War doldrums, finally reaching Ackley on October 19, 1865, and extending services to Iowa Falls on June 1, 1866. ${ }^{11}$ This concern was greatly influenced by leading Dubuque personalities who clearly saw the value of spreading Dubuque's influence to the interior of the state by means of a railway. The corporate officers of the D\&SC and the commercial leaders of Dubuque had been and were increasingly interested in Eldora coal-but not sufficiently enough to alter their projected route to tap these deposits directly. Nevertheless, far-off Dubuque would happily find other ways to assist Eldora in its quest for a railroad.

In January of 1866 the Executive Committee of the Eldora and Steamboat Rock Coal Company (the primary colliery) was invited to consult with Platt Smith and certain other Dubuque capitalists for the purpose of securing aid and assistance sufficient to build a road from Ackley to the mines. ${ }^{12}$ The Dubuque Road desired the Eldora coal for revenue freight, as well as fuel for its locomotives, but the connecting line would be corporately independent of the D\&SC. The Eldorans did agree to link forces with their Dubuque brethren - and the result was the creation of the Eldora Railroad and Coal Company, organized for the purpose of building a railroad from Ackley to Eldora. ${ }^{13}$

The editorial views of $\mathrm{R}$. H. McBride underwent a precipitous change. The St. Louis gateway notion was relegated to a distant second place, while the possibility of securing an outlet via Ackley and the east-west Dubuque Road prospered. By late May, McBride seemed fully to sense the importance of Eldora coal in a larger regional setting: "If this new coal company [ERR\&CC] will perform its part, there

\footnotetext{
${ }^{11}$ Annual report of the Board of [Iowa] Railroad Commissioners, 1896 (Des Moines: State Printer, 1897), p. 221.

${ }^{12}$ History of Hardin County, Iowa, p. 506.

${ }^{13}$ Eldora Ledger, January 31, 1866. According to the History of Hardin County, Iowa, the company was chartered February 7, 1866, see page 506. On Platt Smith see Thomas C. Cochran, Railroad Leaders, 18451890: The Business Mind in Action (Cambridge: Harvard U. Press, 1953), pp. 461-466.
} 
is no reason why the farmers on the prairies miles and miles distant should not get their coal here, for ten and fifteen cents per bushel. The day will surely come when prices like these will rule." ${ }^{14}$ Absence of coal in the prairie lands was taken for granted but it was, nevertheless, a highly desirable commodity-and essential for potential industry. When transported long distances, however, it became very expensive. McBride was certain that Eldora coal, found at such a strategic location, could be marketed at competitive rates within the entire region, and eventually in remote areas. Of course, St. Paul likewise offered strong marketing possibilities.

Also in January, C. C. Gilman of Dubuque, president of the new railroad and coal company, along with numerous other eastern Iowa investors visited the coal banks. McBride noted that the list of officers included no local residents. Control apparently was in the hands of Gilman and the Dubuque clique, but at least one Eldoran, H. L. Huff, was included on the board of directors. ${ }^{15}$

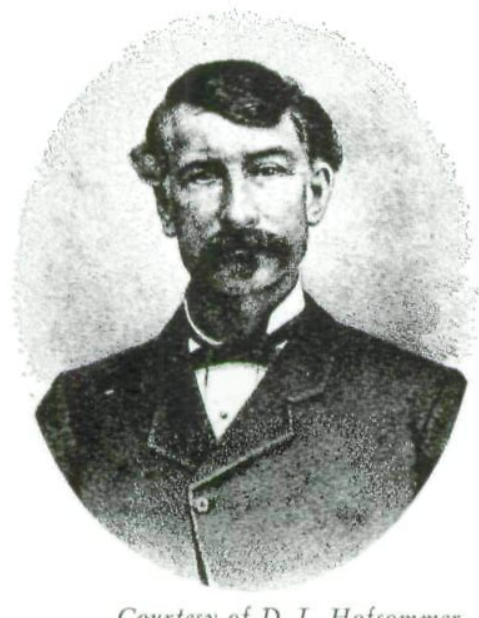

Courtesy of D. L. Hofsommer H. L. Huff

Nevertheless, the dream of an Eldora railroad faded in the summer and fall of 1866 . By the beginning of 1867 , McBride was looking far afield in his quest for a railroad. Building in the neighboring state of Minnesota had progressed to the point where the Winona and St. Peter Road had completed its line to Owatonna, there intersecting the Minnesota Central's route from Minneapolis-St. Paul. It was to Minnesota that McBride addressed himself when he asserted his desire to see Hardin County and central Iowa "meet you at the [state] line and shake hands with you in a manner becoming railroads." ${ }^{16}$ In another

${ }^{14}$ Eldora Ledger, May 23, 1866.

${ }^{15}$ Eldora Ledger, May 30, 1866 and February 20, 1867.

${ }^{16}$ Ibid., January 9, 1867. 
direction, McBride was mildly surprised-but pleased to note - -that Marshalltown increasingly was casting a covetous eye toward the Eldora coal banks. Citizens in that community readily accepted the reverie of industrial and commercial empire; this would come naturally if only they could obtain the inexpensive fuel from Hardin County-but that would take a railroad. However, on January 1, 1867, one year after McBride came to town, the Eldora Railroad and Coal Company seemed moribund, and it appeared that Eldora could only look forward to some obscure day when a branch might be built up from Marshalltown or down from Ackley-but even those prospects seemed remote.

Then, in late January, enthusiastic but controversial rumors were confirmed when McBride wrote of events surrounding the Eldora Road. The publisher's enthusiasm for that concern had lagged considerably during the previous year when construction of the road between Ackley and Eldora had simply failed to materialize. Now the ERR\&CC asserted its desire to complete the road before November of the same year-if only the coal lands and rights of way were deeded over to the railroad when construction was completed. Undoubtedly there were those who considered this an elementary form of blackmail, but McBride counseled acceptance of the railroad plan.

They [ERR\&CC] want a quid pro quo, or in plain English a this for that. If we consent, the road is ours-if not, we must suffer on, suffer ever. It is not our aim to advocate the railroad company's demands, although we know it customary for all local roads to be graded and tied before a railroad company will bother with it. Our design is to cheer and encourage the people, to submit and suffer like a friend who must be helped, that health might return. For the prosperity of a section, a railroad is required; to get this railroad we must bleed. The question is, shall we submit cheerfully to what is good for all, or churlishly kick against suffering a little for the great and general blessing? ${ }^{17}$

In the same edition of the Ledger, bold headlines shouted "Railroad Meeting. Come One Come All!" The object of this assembly on January 26 was to prepare for the regular meeting of the Eldora and Steamboat Rock Coal Company, and to consider the question "shall lands now owned by that or-

${ }^{17}$ Ibid., January 20,1867. 
ganization be transferred to the Rail Road [sic] Company when the cars run into Eldora?"18 McBride, of course, suggested that the community would do well to vote "YES," urging further that "every individual who [could] possibly get out should be in attendance." 19 The Ledger reminded its readers that a number of stockholders of the Coal Company had already agreed to the proposition. Some had donated right-of-way lands. Dubuque capitalist, Platt Smith, promised that he was ready to donate ten thousand ties to be delivered at Ackley immediately. President Gilman was scheduled to be in attendance and would, according to McBride, give "every assurance of his sincerity, and let contract for the road instanter." ${ }^{\prime 2}$ Finally, the Eldora newspaperman argued that the railroad's proposal was "no scheme, no gabble. Comply with this last demand and by next November, Eldora will by rail be connected with the outer world." ${ }^{21}$

On February 5, the Coal Company accepted the proposals of the ERR\&CC. Subsequently, right-of-way land and 1,300 acres in the heart of the coal fields were deeded to the railroad. ${ }^{22}$ In return the ERR\&CC allowed stockholders of the Coal Company " $\$ 30$ per acre, payable in equal amounts of money, stock and bonds of the company," thereby granting considerable local control of the railroad. ${ }^{23}$ Additionally, the Railroad Company agreed to "grade, tie and bridge the road from Ackley to Eldora by November 1st, 1867," but would have until July 1, 1868, to run the cars into Eldora. ${ }^{24}$

McBride was ecstatic! Under the banner, "The Dawn of a Better Day," he editorialized:

The proposed railway from Ackley to Eldora is only fifteen miles in length, but as the first link in the chain that will eventually connect Iowa and Minnesota, we hail it with rejoicing ... Iowa and Minnesota must be joined together before many years, and it will not be long till we can be united with St. Louis. This may be speculation today, but three years will see it well on the way to fulfillment. ${ }^{25}$

Perhaps his aspirations for Eldora had been sparked by a recent letter from W. Morin of Albert Lea, which gave an indication that Minnesota's Freeborn County was interested
${ }^{18}$ Ibid.
${ }^{21}$ Ibid.
${ }^{19}$ Ibid.
${ }^{20} \mathrm{Ibid}$.
${ }^{23}$ History of Hardin County, Iowa, p. 507.
${ }^{24}$ Eldora Ledger, February 6, 1867.
${ }^{25}$ Ibid. 
in the Eldora Road as a possible segment in a future IowaMinnesota interconnection. ${ }^{26}$ Publisher McBride was further intoxicated by railroad mania when he learned that the Des Moines Register now considered the Ackley-Eldora line a "sure thing." ${ }^{27}$ Additionally, the Register suggested that a connecting line be built from Ames to the Eldora Road and thereby reach Minnesota via Cedar Falls and its northern road. The Des Moines writer apparently was deficient in his knowledge of Iowa geography for the suggested routing was anything but direct. However, interest in procuring vertical lines through Iowa was evident in the capital city as well as out of state.

The issue of the Ledger on February 20 boasted enthusiastic headlines: "Hurrah For The Engine. The Railroad To Eldora A Sure Card." McBride felt "certain that the Eldora R.R. Co., [would] in time, be the richest corporation of its size in Iowa." ${ }^{28}$ The editor was overzealous and overenthusiastic perhaps, but an increasing number of diverse and distant communities were taking serious interest in the Eldora Road. Lately the Owatonna [Minnesota] Vedette carried a laudatory article regarding the possibility of connecting its Minnesota Central with the yet-to-be-completed Eldora Road. Mankato likewise was interested in a north-south line, but McBride played down this option.

For reasons that are not entirely clear the Eldora Railroad and Coal Company suddenly found itself unable to comply with the contract as drawn, but asserted its willingness to complete the line if only the Eldora and Steamboat Rock Coal Company would "donate" the coal lands. This would save the Railroad $\$ 30$ per acre in stocks and bonds but would deprive Eldora of its only vestige of local control. ${ }^{29}$ Nevertheless, the railroad was a "must," and to achieve it a little more blackmail could be tolerated. The Coal Company accepted the proposition, and work soon commenced on the railroad.

The contract for grading, tieing, and bridging went to S. L. Dows and Company of Cedar Rapids, and carried the
${ }^{26}$ Ibid.
${ }^{28}$ Ibid., February 20, 1867.
${ }^{27}$ Ibid., February 13, 1867.
${ }^{29} \mathrm{History}$ of Hardin County, Iowa, p. 507. 
stipulation that work must be completed by November $15 .^{30}$ Sufficient stock was sold to pay the contractor for the work, and after the frost had vacated the rich Iowa soil, a newly patented machine used by Dows, "The Railroad Excavator," began building the bed for the road. ${ }^{31}$ This machine employed one or two teams and "could do wonders in its peculiar way." ${ }^{32}$ The construction company solicited ties from the surrounding area, and McBride suggested that this was "a chance for some of [the local] idlers to get to work and do something." ${ }^{33}$ Soon 16,000 ties were on hand at Ackley. ${ }^{34}$

The idea of a St. Paul-St. Louis "Air Line" weighed heavily on McBride's mind as construction began on the Eldora Road. Such an "Air Line," in the publisher's judgment, ought to be designed to serve Owatonna, Geneva (Minnesota), Ackley, and Eldora as it passed from north to south. At the same time, McBride mentally resurrected the old Iowa Central Air Line. ${ }^{35}$ Logically, according to the Eldoran, this road would route itself from east to west via Lyons, Anamosa, and Eldora and thus "cut the state in quarters, Eldora being a pivotal point." ${ }^{36}$ Meanwhile, the Des Moines Register again championed a north-south venture which included Eldora. The new route proposed by the Register was designed to link the capital cities of Iowa and Minnesota via Owatonna and Albert Lea in Minnesota, and Eldora and Ames in Iowa. ${ }^{37}$ McBride enthusiastically embraced this suggestion.

By mid-May S. L. Dows and Company had between fifty and one hundred-fifty hands at work grading the Eldora Road, the line being worked in both directions from midpoint. ${ }^{38}$ McBride left his desk for a day to observe the graders. Later he reported the following:

${ }^{30} \mathrm{Ibid}$. See also Eldora Ledger, February 20, 1867.

${ }^{31}$ Eldora Ledger, March 6, 1867.

${ }^{33}$ Ibid.

${ }^{32}$ Ibid.

${ }^{34}$ Ibid., March 13, 1867.

${ }^{35}$ The Iowa Central Air Line should not be confused with the Iowa Central Railroad, a "paper road" mentioned earlier, nor the Iowa Central Railway, an eventual successor to the Eldora Road. On the Iowa Central Air Line see Robert J. Casey and W. A. Douglas, Pioneer Railroad (New York: McGraw-Hill Book Company, 1948), pp. 124-125, and Ruth I. Preston, "The Lyons and Iowa Central Railroad," Annals of Iowa, IX (January, 1910), pp. 284-301.

${ }^{36}$ Eldora Ledger, March 13, 1867.

${ }^{38}$ Ibid., May 15, 1867 and May 29, 1867.

${ }^{37}$ Ibid, , March 20, 1867. 
Judge Williams' patent excavators are working wonders. He has four great horses abreast, Russian fashion, for each machine. The contrivance weighs about seventeen hundred pounds, scoops up forty hundred weight of dirt in a few minutes, and dumps it in a twinkling. Two men operate the excavator, and with four horses do the work of seven or eight men and teams. ${ }^{39}$

As the grading progressed, the Railroad Company sought additional funds to purchase rolling stock and the necessary iron rail. In order to secure this capital the company issued bonds in the amount of $\$ 400,000$, secured by the usual first mortgage lien on the company's assets: the roadbed, rolling stock, lands, and mineral rights. ${ }^{40}$ A sufficient number of local residents, plus Dubuque capitalists and others, purchased these bonds so that by mid-June the Ledger announced that J. I. Spaulding of Dubuque had been chosen to supply the iron for the entire seventeen miles of construction, with full delivery expected by the end of August. ${ }^{41}$ Concomitantly, McBride announced that "arrangements have gone ahead with the Illinois and Missouri Telegraph Company for the building of a line from Ackley to Eldora, to be complete by the time the cars commence running over the road." ${ }^{42}$

Railroad talk continued to dominate Eldora news during the summer of 1867. McBride took special interest in Charles C. Gilman, who, as far as the publisher knew, was the "youngest Railroad President in the country." ${ }^{43}$ In the opinion of the editor, the 35-year-old Gilman had made "superhuman exertions" on behalf of Eldora. ${ }^{44}$ With such a dynamic leader, McBride was not surprised to learn that the stocks and bonds of the ERR\&CC were being quoted higher than those of the larger Dubuque and Sioux City Road-a fact which the Eldora newspaperman gloatingly reported to his readers. ${ }^{45}$

In early July the location for Eldora's depot had been selected, and, according to the Ledger "the locality gives general satisfaction." ${ }^{\prime 6}$ At the same time there were 300 men at work on the grade who recently had been paid wages in the

${ }^{39}$ Ibid., June 12, 1867.

${ }^{40}$ History of Hardin County, Iowa, p. 507.

${ }^{41}$ Eldora Ledger, June 26, 1867.

${ }^{42} I$ bid.

${ }^{44}$ Ibid.

${ }^{43}$ Ibid., May 15, 1867.

${ }^{46}$ Ibid., July 3, 1867.

${ }^{45}$ Ibid. 
amount of $\$ 8,000 .^{47}$ Indeed, track laying could be expected in October, and the Road, in McBride's estimation, should be complete before winter. It was a bright moment; the Ledger considered that "the inventive genius of mankind has, up to this time, furnished no parallel to . . . the building of railroads across the prairies of the West." ${ }^{48}$ In far-off Chicago the Evening Journal commended the Eldora Railroad and Coal Company as the first Iowa railroad to be built with local capital. ${ }^{49}$ It was a grand season.

However, the Dubuque and Sioux City Road was leased to the Illinois Central Company on October 1, 1867, ${ }^{50}$ and there was legitimate concern regarding the ramifications this development might have for the Eldora Road. Meanwhile, rail was being stockpiled for the ERR\&CC at Dubuque and by November thirteen carloads of iron had arrived at Ackley. ${ }^{51}$ Noting the presence of the rail at Ackley and aware that the bridge over the Iowa River at Steamboat Rock was nearly completed, McBride felt that the line could yet be railed before winter if only weather conditions remained favorable. But hope faded with the first snow flurries, and then came devastating news from Illinois: it was a glum Eldora which learned that the agreements reached earlier between the Dubuque and Sioux City Line and the Eldora Road would not be honored by the Illinois concern. ${ }^{52}$ There was plenty of coal in Illinois for the locomotives of the Illinois Central, and large "Eastern" carriers such as this one need not court the minuscule interchange traffic that might come from a yet-tobe-completed "plug" line.

Construction ceased on the Eldora right-of-way; the future of the Road was in grave doubt. Yet McBride's enthusiasm did not flag. In the fall of 1867 residents of Franklin and Cerro Gordo Counties raised money to survey a line from Ackley to Austin, Minnesota. These neighboring counties

${ }^{47}$ Ibid., July $24,1867$.

${ }^{48}$ Ibid., August 7, 1867.

${ }^{49} \mathrm{Ibid}$., September 11, 1867. It would be hard to verify the accuracy of the Journal's statement.

${ }^{50}$ Carlton J. Corliss, Main Line of Mid-America: The Story of the Illinois Central (New York: Creative Age Press, 1950), p. 150.

${ }^{51}$ Eldora Ledger, October 9, 1867 and November 6, 1867.

${ }^{52}$ The M\&StL Railroad Company History (Minneapolis: The Minneapolis and Saint Louis Railroad Company, 1916), p. 7. 
quickly pointed out that the Minnesota Central, now in operation between Minneapolis-St. Paul and Owatonna, had Austin as its eventual goal, and an eighty mile stretch was all that separated Ackley and the longed-for St. Paul connection. ${ }^{53}$ Moreover, the Eldora, Nevada and Des Moines Railway was organized at a meeting on December 28 in Nevada. ${ }^{54}$ The goals of the new corporation were implicit in the title: to link Eldora with Des Moines via Nevada. Among the directors of this ambitious concern were three Eldorans, including H. L. Huff, who also was a director of the ERR\&CC. In those same late days of 1867 Marshalltown reasserted the argument that the capital cities of Hardin and Marshall counties should be linked by rail. In an intoxicating way it seemed as if every community to the north and south of Eldora was wooing her with rails. But McBride was forced to admit that the reality of a railroad was elusive.

Meanwhile President Gilman and Platt Smith tried to lease the Eldora Railroad and Coal company to the Illinois Central. ${ }^{55}$ Should negotiations with the Illinois carrier end in failure, the ERR\&CC would, Gilman announced, consider the extension of its line down the Iowa River Valley to a connection with the Cedar Rapids and Missouri River Railroad at or near Marshalltown. The completion of the line from Ackley to Eldora plus new construction to link Eldora and Marshalltown would afford the residents of Hardin County outlets to two strong east-west carriers and thereby negate the problems of monopoly that come with single option routings. Too, there was the possibility that the CR\&MR might be enticed to lease the entire Eldora Road. ${ }^{56}$

Track work north of Steamboat Rock progressed intermittently during the winter months, and regularly scheduled train movements were planned to begin between Ackley and Steamboat Rock the first week in March. ${ }^{57}$ Eldora would have to wait a little longer, but at least the Iron Horse was moving closer. At the same time it was announced that the ERR\&CC would send a corps of engineers to survey a line from Ackley to Mankato, Minnesota. By now Mankato, Albert

${ }^{53}$ Eldora Ledger, October 30, 1867.

${ }^{54}$ Ibid., January 11, 1868.

${ }^{56}$ Ibid.

${ }^{55}$ Ibid., February 29, 1868.

${ }^{57}$ Ibid. 


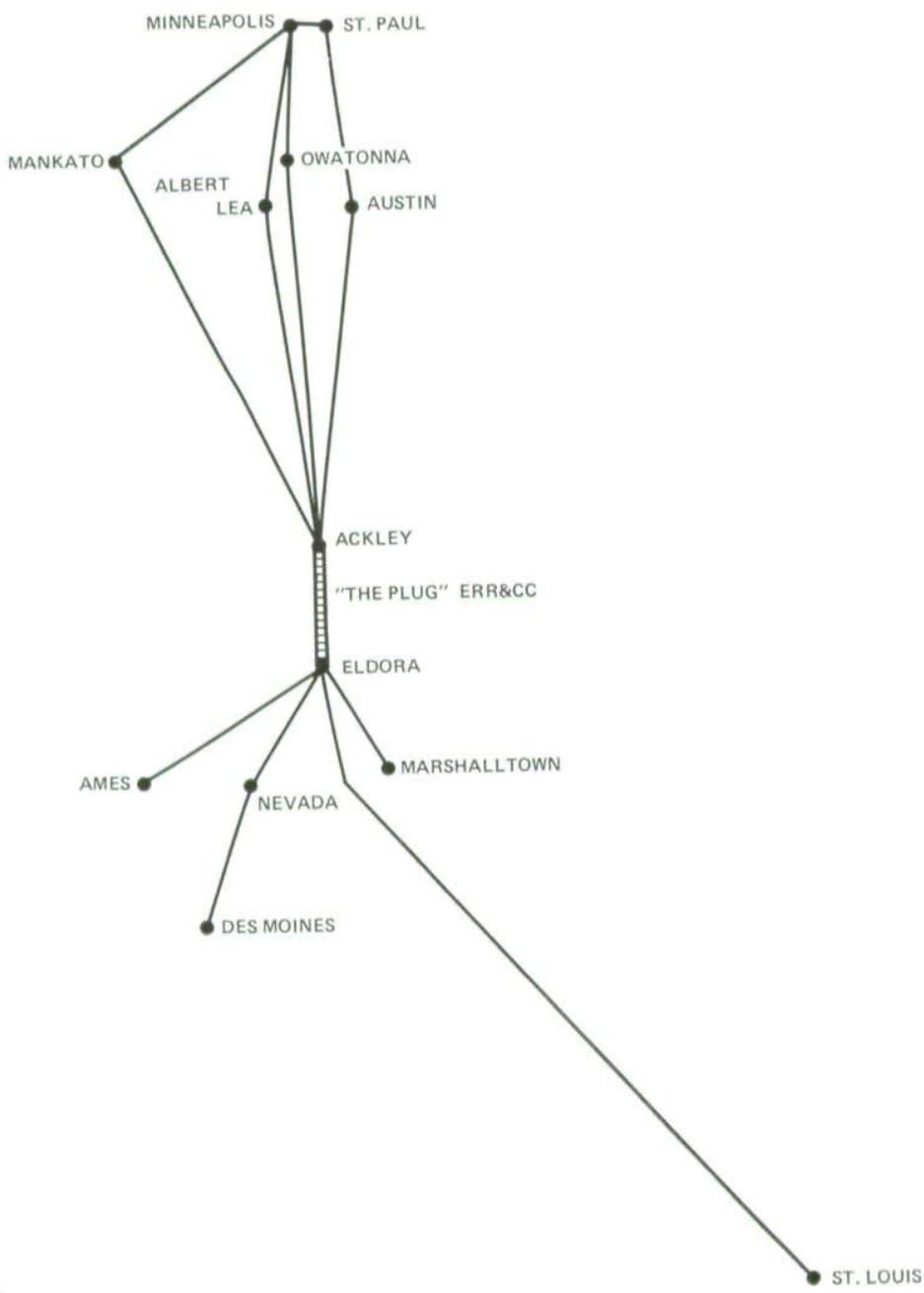

In the late days of 1867 it seemed as if every community to the north and south of Eldora was wooing her with rails. This map suggests the location of Eldora as the hub of a transportation wheel, proposed rail lines converging on the capital of Hardin County, Iowa from a variety of northern and southern communities. 
Lea, Austin, and Owatonna were hoping to link the fledgling Eldora Road with some sort of north-south transportation scheme in Minnesota. How nice it was to be wooed! Perhaps Eldora could play each of these northern contenders against the others. However, there was some danger in hesitation. Other "paper" or fledgling concerns also were interested in linking mid-Iowa and Southern Minnesota with the cities of Minneapolis and St. Paul. ${ }^{58}$

During the early months of 1868 Judge Jonathan Porter was active in securing aid for the proposed northern extension of the Eldora Road. This Eldoran visited Franklin and Cerro Gordo counties in Iowa, as well as various Minnesota communities, where he admitted that there were several proposed north-south projects, each of which might provide great benefits for those concerned. However, Judge Porter suggested that his plan would be more beneficial than any of the others. In this regard he contended that his proposed St. Louis and St. Paul Railway would bring pine to local markets, supply coal to the north, facilitate year-round grain movements to any distant market, and promote the iron interests. Porter's project was hotly contested by the Iowa and Minnesota Railroad, a "paper" company which hoped to build a road through Franklin and Cerro Gordo counties west of the route postured by the St. Louis and St. Paul Line. The I\&M was projected to link Iowa Falls, Eldora's arch-rival, with Mason City, and there was talk of future construction to connect Des Moines and St. Paul. ${ }^{59}$

Feeling the press of time but not yet willing to make a final commitment to any of the aspiring Minnesota localities, the forces of Judge Porter met in Mason City to draw incorporation papers for the St. Louis and St. Paul Railway. ${ }^{60}$ This organization was designed to build a road from Ackley to Hampton in Franklin County, Mason City in Cerro Gordo, and Northwood in Worth County, thence to the Iowa and

${ }^{58}$ Most of these plans called for the linking of Des Moines with Saint Paul and generally followed routes of river valleys, viz. Des Moines River, Boone River, and Iowa River. Another path was considered up the Cedar Valley but here the purpose was to link Burlington, Cedar Rapids, Waterloo and possibly Saint Louis with the North Star State.

${ }^{59}$ Eldora Ledger, March 14, 1868.

${ }^{60}$ Ibid., March 28, 1868. 
Minnesota state line for a connection with an as yet unspecified Minnesota carrier. ${ }^{61}$ Thus far Porter's project was simply a "paper railroad," but it did provide the proper vehicle to compete with the "paper" Iowa Falls Road.

By mid-April cars of the Eldora Road were making regular trips as several shipments of potatoes, corn, and coal moved out of the Steamboat Rock railhead. ${ }^{62}$ At this time the rails had been thrust about one mile beyond the Iowa River in order to serve the coal mines properly. The depot at Steamboat Rock was nearly completed, and McBride was happy that his neighbors were enjoying the intoxication that comes with being a railhead. However, there was a touch of envious consternation in his commentary regarding the newly heard sounds of an engine whistle; "The continual 'tooting' of that locomotive whistle throws us into a commotion, and makes us think we are 'e'en a most' a railroad town. . . . Stop that whistle, or [the engineer] may hear it in his sanctum and have the bloom curdle in his veins." ${ }^{\prime 3}$

To the north, engineers of another type by late April had surveyed to a point north of Chapin on the route of the St. Louis and St. Paul Railroad, and before long the Ledger reported that the entire line had been studied. ${ }^{64}$ The Minneapolis Tribune looked to the building of the Eldora Road and the St. Louis and St. Paul Railroad with special favor. Minneapolis desired the immediate construction of three major lines that would link its flour mills with St. Louis, Omaha or Sioux City and Lake Superior-but most of all, the millers wanted the type of St. Louis outlet that was supported by a J. H. McBride, Judge Porter, and other Eldorans. ${ }^{65}$

To the south, Eldorans considered the merits of three separate railroad expansion programs: Eldora to Ames; Eldora to Des Moines via Nevada; and Eldora to Marshalltown. Each possibility had merits insofar as southern Hardin County was

${ }^{61}$ Ibid.

${ }^{63}$ Ibid.

${ }^{62}$ Ibid., April 11, 1868.

${ }^{64}$ Ibid., April 25 and May 9, 1868.

${ }^{65}$ Ibid., May 2, 1868. On Minneapolis, the flour interests and their railroad hopes see Frank P. Donovan, Mileposts On The Prairie (New York: Simmons Boardman, 1950), pp. 1-60. See also Charles B. Kuhlmann, "The Influence of the Minneapolis Flour Mills Upon the Economic Development of Minnesota and the Northwest," Minnesota History, VI ( June, 1925), pp. 141-154. 
concerned. A line to Ames offered excellent routing for Pacific traffic via the CR\&MR and the Union Pacific. The Des Moines option would connect Hardin County directly with the state capital and provide a connection with the CR\&MR at Nevada. The Marshalltown possibility would link the Marshall and Hardin county seats and allow a CR\&MR connection. The Eldora editor found the task of sorting out the best prospect a heady business.

There was a running and often bitter duel between the Eldora Ledger and the Iowa Falls Hardin County Sentinel, a feud involving the publishers of the two periodicals. At times vicious, these competing journalists constantly argued the superiority of their communities and their respective newspapers. Indeed, Eldora and Iowa Falls then were engaged in a great court case to determine if the temporary county seat at Eldora would be confirmed. Iowa Falls had been a "railroad town" since the arrival of the Dubuque and Sioux City Road and was currently laboring hard for the construction of the proposed north-south Iowa and Minnesota Road. Eldora had yet to welcome its first train of cars but the "Plug," as the Iowa Falls publisher derisively labeled the ERR\&CC, was close at hand.

The possibility of incorporating the Eldora Railroad into the line of a major vertical carrier was constantly in McBride's thoughts. Thus, it is not surprising to find the Ledger fairly bursting with enthusiasm for the "paper" StL\&StP. Directors of that concern met again at Mason City on May 6 to accept the report of a civil engineer, Hermon Thiel, who estimated the construction costs of the proposed 68.9-mile line at $\$ 150$,$060{ }^{66}$ Thiel stated that his survey provided for easy grades and light curves on a route that would pass from Ackley to the state line via Hampton, Mason City, and Northwood. The engineer noted that it was but another forty-three miles to a connection with the Minnesota Central at Owatonna, while E. C. Stacy of Albert Lea had already attended to the business of incorporating a connecting link-The Owatonna and State Line Railroad. ${ }^{67}$ The election of StL\&StP officers and

${ }^{66}$ Eldora Ledger, May 16, 1868.

${ }^{67} \mathrm{Ibid}$. At this point it is not entirely clear whether or not the Owatonna and State Line Railroad was designed to serve Albert Lea and 
directors took place at the same Mason City meeting. McBride was proud that two local men were placed in positions of leadership: Judge Jonathan Porter being named Vice-President, while H. L. Huff became a member of the directory. Albert Lea's E. C. Stacy was elected president of this company although he simultaneously was chief executive of the Owatonna and State Line Railroad. A. B. Tuttle of Mason City was named treasurer of the StL\&StP, and B. R. Hartshorn, of the same community, was selected secretary. The directors, like Huff, represented "on line" communities. ${ }^{68} \mathrm{Du}$ buque interests were conspicuously absent from the list of officers and directors of the StL\&StP.

Meanwhile, Charles Gilman was in New York to promote the sale of Eldora Railroad and Coal Company securities. Readers of the ERR\&CC prospectus, which Gilman was distributing, undoubtedly noted the heavy emphasis which was placed on the Hardin County coal deposits. In the typical flowery prose of the period, Eldora's chief natural resource was lauded. ". . . In quality, this coal does not vary materially from that of Illinois or in other parts of Iowa, possessing this remarkable characteristic, however, which makes it valuable for fuel purposes in burning to ashes without fusing or 'clinkering." "69 Before returning to Iowa, Gilman arranged to "purchase passenger cars, locomotive and other equipment, absolutely called for by the increased business on the Eldora Railroad." ${ }^{70}$ Business on the local road was good, with heavy shipments of wheat, corn, potatoes, fire clay, and coal moving daily from Steamboat Rock to the junction at Ackley.

It became increasingly clear that the Illinois Central would handle traffic to and from the "Plug," but that the larger road had little interest in owning or leasing the line. Rebuffed by the IC and fearful of the difficulties inherent in

Geneva as earlier proposals had suggested. However, Albert Lea was the residence of E. C. Stacy and it seems safe to assume that the seat of Freeborn County would be served by Stacy's Road. Later evidence indicates that Albert Lea definitely was a goal for the connecting Saint Louis and Saint Paul Company,

${ }^{68}$ Ibid.

${ }^{69}$ Prospectus of the Eldora Railroad and Coal Company, 1866, quoted in History of Hardin County, Iowa (Springfield, Illinois: Union Publishing Company, 1883), p. 339.

${ }^{70}$ Eldora Ledger, May 16, 1868. 
any single-line connection, the management of the Eldora Railroad and Coal Company came to grips with reality-it was necessary to expand or wither. Surveys had been made earlier in a northerly direction, but the machinations of the StL\&StP and the rival Iowa and Minnesota Railroad precluded additional railroad involvement in that narrow corridor. President Gilman thus looked to the south and made a firm commitment in the late spring of 1868 to finish the "Plug" into Eldora, thence down the Iowa River valley to a connection with the Cedar Rapids and Missouri River Railroad. ${ }^{71}$ For months conjecture about this type of expansion had been widespread, and Eldorans generally greeted the news with enthusiasm. But Gilman had even more news. After careful consideration, the President of the ERR\&CC came to the conclusion that his company had a ready and profitable market for coal in the St. Paul area. The demand for fuel in that region was such that coal brought $\$ 2.50$ per ton. Knowing this, Gilman proposed to have his ERR\&CC "iron" the St. Louis and St. Paul route, provided that concern could arrange for financing of all other aspects of construction. ${ }^{72}$ Should this new stretch of road come under Gilman's control, the ERR\&CC would have, when completed, a line of operation extending from the Minnesota state line to the Cedar Rapids and Missouri River Road at or near Marshalltown. Extension of the Eldora Road southward to the CR\&MR would have immediate short range benefits, while a connection with the markets of neighboring Minnesota held long range possibilities.

Currently the "Plug" was performing acceptably in its own right. Receipts for the line were averaging $\$ 300$ per day, and McBride opined that this was "mighty clever for a young railroad only twelve miles long." " Perhaps the bulk of the credit for the road's performance was due to President Charles Gilman who increasingly sought to control the road by buying out certain of the original investors. ${ }^{74}$ Gilman purchased a home in Eldora and soon moved his family to Hardin County. No "eastern capitalist," Gilman was a local hero, and all the

${ }^{71}$ Ibid.

${ }^{73}$ Ibid., May 30, 1868.
${ }^{72}$ Ibid., May 23, 1868.

${ }^{74}$ Ibid., June 20, 1868. 
news he released through McBride served to increase the status of the already popular railroad executive.

From the time the Eldora Road opened for business, its sole locomotive had been the VIXEN, "a light draft engine [which was] given to sparking considerably." 75 The volume of business in the spring of 1868 increased to the point where Gilman had the pleasant task of ordering a "large sized powerful engine; . . . a jewel . . . and worthy to sound its throat on the beautiful prairies of Iowa." ${ }^{\text {"n }}$ Moreover, Gilman announced that work would commence at once on the grade between the mines and Eldora. ${ }^{77}$ With the ties down, the rails would not be long in arriving. Plans also went forward to build a depot at Ackley near the junction of the "Plug" and the Illinois Central. ${ }^{78}$

President Gilman was serious about extending the road from Eldora down the Iowa River valley to the CR\&MR, but he had never clearly indicated that Marshalltown was the desired goal. This form of deceptiveness was generally employed by railroad promoters of the period and the implications were not lost on communities aspiring to receive initial or additional rail service. Should Gilman build his road to a point on the CR\&MR some few miles west of the Marshall County seat, it was clear that Marshalltown's future would be seriously endangered. Gilman allowed the seeds of this threat to germinate in the minds of the Marshalltown citizenry, and not surprisingly a letter soon came from State Senator Rice, a resident of the city in question. Rice naturally urged Gilman to build the line by way of Marshalltown. The railroad president responded to this suggestion by stating that his company was anxious to extend the road and would do so immediately "if sufficient encouragement were given by the people along the line." ${ }^{\prime 9}$ Gilman was practicing the classic form of railroad bribery; Marshalltown knew it, but the outcome remained in doubt.

On another front, the officers of the Eldora, Nevada and

${ }^{75}$ Ibid., June 27, 1868.

${ }^{76}$ Ibid., May 30, 1868 and Dubuque Times, an updated story in the Eldora Ledger, July 4, 1868.

${ }^{77} \mathrm{Ibid}$., June 13, 1868.

${ }^{78}$ Ibid., June 6, 1868.

${ }^{79}$ Dubuque Herald, an updated story appearing in the Eldora Ledger, June 13, 1868. 
Des Moines Railroad boasted that they had been successful in raising $\$ 60,000$ through subscriptions and taxes. The arguments mounted in defense of their corporate goals were impressive. First, they stated that the completion of their road would form an "Air Line" from Eldora to the state capital of Des Moines. Commercial advantages were obvious, as were the opportunities afforded by prospective passenger traffic. Second, construction of their line would bring a direct connection with the CR\&MR, promote westbound shipments for the Union Pacific, and allow Eldora coal to compete in the Missouri River marketing area. ${ }^{80}$

The Eldora Ledger enthusiastically endorsed any railroad project that might augur well for the local area. But McBride's lead story on June 20 was headlined "Marshalltown Vs. Nevada"; the implication being that one line or the other would finally be constructed-not both. McBride discussed the virtues of the Nevada route and then turned to the Gilman project of linking Eldora with the CR\&MR. The Eldora publisher acknowledged that Gilman's route would put Eldora about seven miles closer to the CR\&MR and advanced the notion that the Eldora Road would not stop at the junction of the Cedar Rapids Road but would, in fact, build on to the connection of the Chicago, Rock Island and Pacific at Grinnell. Such a line would yield two more Illinois connections for the Eldora Road, provide an outlet for western traffic via the CR\&MR, and make a circuitous connection with Des Moines via Grinnell and the Rock Island Line. McBride saw the consummation of the various Gilman projects as an important step in linking St. Louis with St. Paul by way of Eldora and thereby establishing "a great north and south thoroughfare" similar to the one provided by the Illinois Central in Illinois." ${ }^{11}$

Yet after surveying the virtues of the two choices, McBride rather surprisingly opted for the Nevada proposal, asserting that "Eldora would like to have a road to Marshall [sic] and another to Nevada, but if only one is vouchsafed us now, let us get direct communication with Des Moines . . ."82 There was little consistency in McBride's argument. After affirming his affection for the Nevada route, the Eldora

$$
{ }^{80} \text { Eldora Ledger, June 20, } 1868 . \quad \quad{ }^{81} \text { Ibid. } \quad \quad{ }^{82} \text { Ibid. }
$$


journalist chided Marshalltown for failing to effectively woo Gilman and the "Plug." If Marshall County would supply general financial backing to link itself with Hardin, the financial strain for the Nevada project would be eased, and Eldora, as McBride really hoped, would then have two significant southern outlets. Moreover, the Ledger publisher had an abiding faith in any Gilman project, for "he has associated with him several eastern gentlemen of position and wealth, who are able to willing to back him in any project he deemed feasible." ${ }^{\prime 3}$ McBride and Eldora itself could, it seemed, afford to be inconsistent and somewhat smug.

In the early summer of 1868 the Eldora Road operated two regularly scheduled trips per day from Steamboat Rock, "making close connections at Ackley with East and West trains of the D\&SCRR [sic]." ${ }^{4}$ These trains, operated by Conductor Zublin and Engineer C. Vedder, returned to Steamboat Rock and there connected with stages for Eldora, Xenia, Albion, and Marshalltown. ${ }^{85}$ Stagecoach service between Eldora and Steamboat Rock was augmented by a "hack line of omnibuses" operated by B. E. Deyo. ${ }^{86}$

The arrival of the Iron Horse in Eldora thus was imminent, and each new development brought much excitement along the Iowa River valley. In June, McBride reported that construction on the two-storied thirty by seventy-foot depot at Eldora was progressing nicely, and he contended that it would be the "nicest depot" between the Iowa and Mississippi Rivers. ${ }^{87}$ At the same time the "Plug" took delivery of "a new and splendid passenger and baggage car" with patent ventilation and boasting green enameled cushions recently outshopped by Jackson and Sharpe of Wilmington, Delaware. ${ }^{88}$

With the arrival of the new passenger car, Eldorans were

${ }^{83}$ Ibid.

${ }^{84} \mathrm{Ibid}$. Departure from Steamboat Rock was scheduled for 4:50 A.M. and 5:40 P.M. Departure from Ackley was scheduled for 7:15 A.M. and $7: 15$ P.M.

${ }^{85}$ Eldora Ledger, June 20 and June 27, 1868.

${ }^{86}$ Ibid., May 2, 1868.

${ }^{87}$ Ibid., June 27, 1868.

${ }^{88}$ Dubuque Times, an undated story appearing in the Eldora Ledger, July 4, 1868 . 
promised an excursion on the Fourth of July. ${ }^{89}$ McBride heralded the announcement with the banner "Good Time Coming," and counseled his readers to "prepare their good clothes for a grand jubilee and excursion July next. [Local residents would] . . . have a free ride over the Eldora Railroad, and in that Companys passenger cars." ${ }^{\text {"0 }}$ Charles Gilman was highly appreciative of the fine co-operation that Eldorans had given his enterprise. Therefore it was fitting that he repay the compliment by providing an excursion over the new road - and its Ackley connection as well! Soon the project mushroomed into the social event of the season, perhaps of the decade. Arrangements were made with the Illinois Central to handle the excursion train over its line from Ackley to Cedar Falls and then north to Nashua. Inasmuch as the rails had not yet arrived in Eldora, the excursion began at Steamboat Rock. Departure time for the "Special" was set at seven in the morning with the return to be at eight in the evening. ${ }^{91}$ Earlier indications that the excursion would be "free" hinged on the notion that the excursion train would operate solely over the rails of the Eldora Road. However, in order to afford the ambitious outing over the IC rails to Nashua, Gilman reluctantly agreed that it would be necessary to charge every excursionist one dollar for the round trip. ${ }^{92}$

The weekly Eldora Ledger of July 11th carried McBride's flowery description of the tour to Nashua. By all indications it was a gala day: the weather was perfect for an excursion, and a grand time was had by participants and observers alike. The depot at Steamboat Rock thronged with people who began arriving at dawn. Soon Engineer Vedder sounded the whistle of the VIXEN, and the grand entourage made its way up the short but steep grade out of the Iowa River valley onto the prairie for its run to Ackley. The country along the route of the Eldora Road was typical of the best farm land in Iowa, and the excursionists undoubtedly took pride in viewing the rich panorama from the cars of "their" railroad. After a "thirty minutes flight" the train pulled to a stop at Ackley

${ }^{89}$ Eldora Ledger, May 23, 1868.

${ }^{90}$ Ibid., June 6, 1868.

${ }^{91}$ Ibid., June 20, 1868.

${ }^{2}$ Ibid. 
where the Eldora cars were added to those of the Illinois Central. ${ }^{93}$ It was a lengthy train, carrying approximately 1,500 excursionists. Appropriately the Eldora cars, including "the handsome coach just received by the Eldora R.R., led the van, while green boughs and small flags fluttered and waved over all."

The "Special" whistled its arrival at Nashua around noon. There were numerous activities planned by the civic-minded Nashuans, but most of the excursionists first addressed themselves to the task of consuming the generous picnic lunches which they had packed along. There was plenty of time for listening to a variety of scheduled orations as well as ample opportunity to enjoy the fireworks, see the "sights," or merely to lounge under a generous shade tree. Nashua was pleased to act as host for these several hundred Iowa visitors; greetings were extended by the mayor and other civic leaders. Residents of Hardin County, the Eldora Railroad, and Charles Gilman received especially laudatory salutations. It was a grand celebration, in the best tradition of the national birthday, and most visitors were reluctant to board the cars for departure at 4:30.

The return trip found a number of excursionists in a reflective mood, many concerning themselves with a review of the trials which had plagued Eldora in its quest for a railroad. It was rather generally concluded that Charles C. Gilman, whom McBride described as "not good looking" but "a western working man," had been responsible for the arrival of the steam cars along the Iowa River valley. ${ }^{95}$ In one of the coaches a group of men had fortified their general patriotism with some corn whiskey, and as they considered Gilman's contributions, one of their number composed the following:

Here's a health to President Gilman,

Drink it down.

That's his 'plug,' we now can scan,

Drink it down.

For if you want some railroads,

He's the boy to build 'em.

Drink it down, drink it down, drink it down. ${ }^{96}$

It was almost dark when the Illinois Central delivered the

${ }^{93}$ Ibid., July 11, 1868.

${ }^{95}$ Ibid.

${ }^{94}$ Ibid.

${ }^{96}$ Ibid. 
Eldora cars to Gilman's Road at Ackley. Shortly thereafter the Eldora engine had the "home" cars in tow, and as the train hurried home McBride humorously observed:

When the VIXEN whistled some,

The calves stuck up their tails and run. ${ }^{97}$

The Nashua "Fourth of July" outing was a tremendous success. Gilman provided area residents with some extremely pleasant memories, but more importantly Gilman had taken opportunity at Nashua to confirm the rumor that a number of corporate changes soon would take place. Simply stated, the Eldora Railroad and Coal Company was to be dissolved, railroad operations to be assumed by the new Iowa River Railway, mining operations to be retained by the Eldora Coal Company. ${ }^{98}$ The Iowa River Railway, Gilman announced, would authorize construction of a road from Eldora south to the CR\&MR. ${ }^{99}$ Beyond the junction with the Cedar Rapids Road, the Iowa River Railway projected a line of construction "following down the sixteenth meridian of longitude to the Missouri state line," thus planning to effect a junction with a St. Louis company at that point. ${ }^{100}$ Meanwhile, the production of coal from the Eldora banks was increasing, and McBride predicted an output of five hundred tons per day during the coming winter season. ${ }^{101}$ All of this spoke well of Eldora's future, and the Ledger editor was motivated to predict that "five years from now will see the largest town west of Dubuque." 102

Shortly after the Fourth of July, track laying began along the line from the coal mines to Eldora, and by the 18th McBride confidently announced that the rails were within two and one half miles of town. ${ }^{103}$ During the last week in July Eldora became a railroad town and the permanent county seat-all in the same day. ${ }^{104}$ Almost simultaneous with the arrival of the construction crew came a messenger from Des Moines with the news that the Iowa Supreme Court had resolved the lengthy litigation regarding the location of the
${ }^{97}$ Ibid.
${ }^{100}$ Ibid.
${ }^{98}$ Ibid.
${ }^{99}$ Ibid.
${ }^{101}$ Ibid.
${ }^{102}$ Ibid.

${ }^{103}$ Ibid., July 18, 1868.

${ }^{104}$ Ibid., August 1, 1868. Unfortunately, McBride does not indicate the exact date. 
county seat in favor of Eldora. Celebrations to herald the arrival of the Iron Horse had been scheduled at the depot; these festivities were carried out while another celebration was held at the court house. Bonfires burned until midnight, ${ }^{105}$ a "salute of 100 guns was fired, . . . speeches were made by those not 'too full of utterance,' and 'all went merry as a marriage bell." "106 On hand for the driving of the last spike was President Gilman, along with Horace Abbott, Thomas Kensett, and Jonathan Gilman, all Baltimore capitalists. ${ }^{107}$ These Maryland gentlemen became closely associated with the new Iowa River Railway and greatly assisted Gilman and local supporters in a quest for the "foreign" capital that was essential if the line was to be extended.

By August 10, Agent John Gilman, formerly company representative at Steamboat Rock, accepted the first freight shipment at Eldora when John Findley sent several cars of cattle to market. ${ }^{108}$ Business flourished at the new railhead, and shortly the company took receipt of twelve new boxcars which were immediately pressed into service. ${ }^{109}$ The new locomotive, ordered earlier to handle the increasing traffic, arrived on August 20. ${ }^{110}$ Christened THOMAS KENSETT, this beautiful twenty-six-and-one-half-ton coal burner came directly from the East Boston shops of McKay and Aldus and was the pride of the road for some years. ${ }^{111}$ Construction of the Eldora depot had been completed by a Dubuque contractor Henry Graham, who now labored at the installation of a forty-five-foot turntable. The location of the turntable at Eldora was especially important in that it symbolized permanence. Indeed, Charles Gilman announced that the headquarters of the Iowa River Railway would remain in Hardin County where he could properly direct the operations of the

${ }^{105}$ Ibid.

${ }^{106}$ History of Hardin County, Iowa, p. 507. A similar celebration was held at the opposite end of the line where a dance was held at the Ackley House. See Ackley World Journal, "Centennial Edition," August 1, 1957.

${ }^{107}$ Eldora Ledger, August 1, 1868. It is not known if Jonathan Gilman was related to Charles Gilman.

${ }^{108}$ Ibid., August 8, 1868. It is not known if John Gilman was related to Charles Gilman.

${ }^{109}$ Ibid., August 22, 1868.

${ }^{110}$ Ibid.

${ }^{111}$ Ibid. 


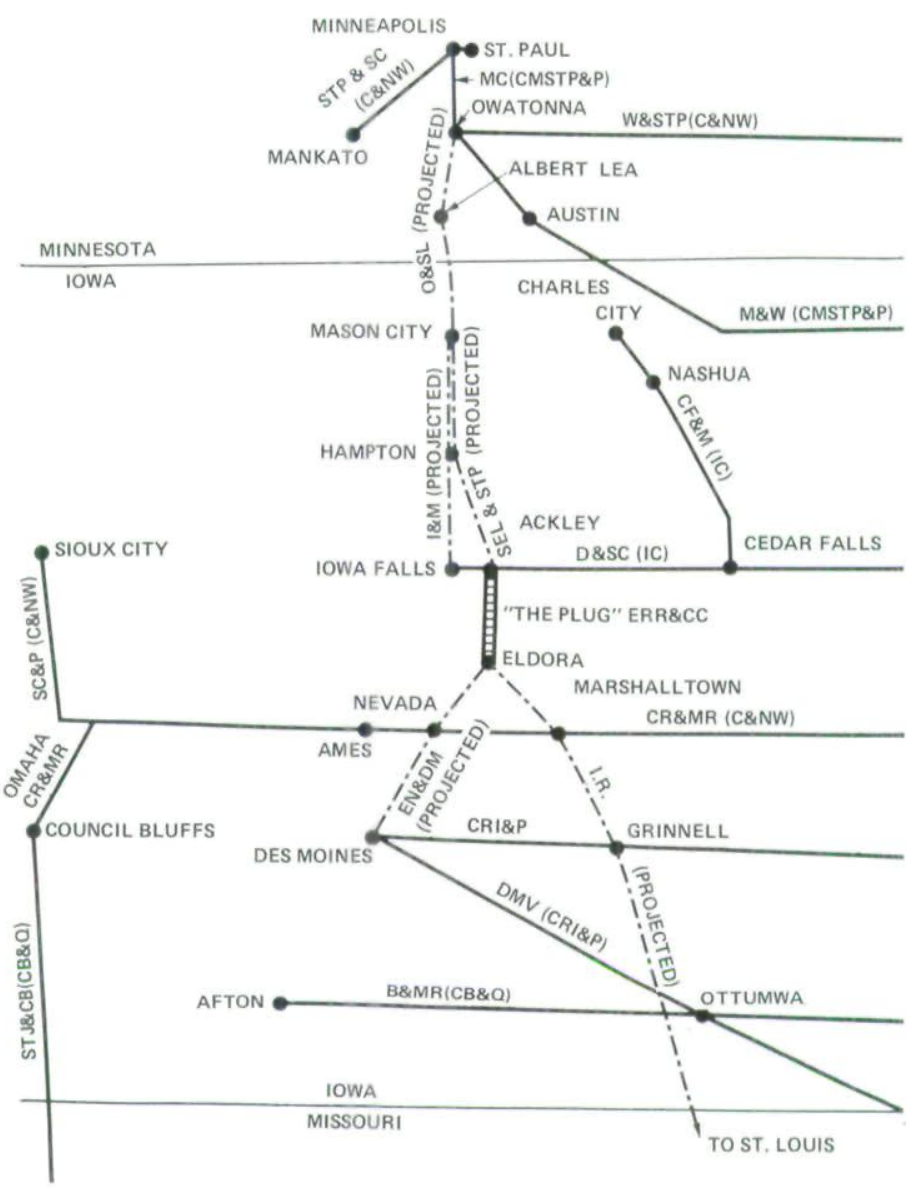

When Gilman's "Plug" arrived in Eldora during the last week of July, 1868, the Iowa railroad map looked like this. In a few years the Eldora Road was extended both north and south and became, as R. H. McBride prophesied, part of a great north-south thoroughfare. 
railroad while at the same time exercise his presidency of the Eldora Coal Mining Company. ${ }^{112}$

As summer faded into fall, the volume of both freight and passenger traffic steadily increased. Coal was moving well, agricultural products were shipped daily, inbound merchandise traffic was good, and passenger volume mushroomed. The daily (except Sunday) schedule for September, 1868, was:
Leave Eldora
4:30 A.M. 4:30 P.M.
Arrive Ackley
6:15 A.M.
6:15 P.M.
Leave Ackley
7:15 A.M.
7:30 P.M.
Arrive Eldora
9:00 A.M.
9:00 P.M. ${ }^{113}$

Passengers and freight were handled on all trains. Connection was made at Ackley with Illinois Central trains and at Eldora for the Marshalltown stages. In Eldora, B. E. Deyo, owner of the Eastern House, operated a free omnibus to and from the railroad station. ${ }^{114}$ Modern life had truly come to the capital of Hardin County.

The end of the construction season saw graders at work between Ackley and Hampton along the route of the St. Louis and St. Paul Line. The next season would surely see the grading completed and perhaps some iron would be put down. It was not yet certain which Minnesota community would eventually be selected as the intermediate point between the IowaMinnesota boundary and Minneapolis-St. Paul. Mankato, Albert Lea, Owatonna, and Austin remained the primary candidates. The precise routing bothered Eldorans little; getting the local road completed was the important thing.

To the south, residents of Marshall County finally saw the wisdom of assisting the Gilman project. Earlier requests for support were received with lethargy in Marshalltown and Marshall County, but when it became evident that engineers of the Iowa River Railway were surveying a route through Marietta to a junction with the CR\&MR, south and west of

${ }^{112}$ Eldora Ledger, September 19, 1868. Also, Prospectus of the Iowa River Railway, (1869), p. 26. Articles of incorporation were filed July 8,1868 but it is not clear just when full corporate control of the railroad portion of the Eldora Railroad and Coal Company passed to the Iowa River Railway. By mid-September the Eldora Ledger was referring to the railroad as the I.R. Ry, rather than the Eldora Road.

${ }^{113}$ Eldora Ledger, September 19, 1868.

${ }^{114}$ Ibid., August 29, 1868. 
Marshalltown, there was a definite change of heart. The affected townships promptly voted to aid in the amount of $\$ 80,000$ with certain additional benefits to be paid "on condition of the road being built." ${ }^{115}$ Thereupon, Gilman ordered a new survey to run the line directly to Marshalltown! The "twenty-seven miles, from Eldora to Marshalltown, was put under contract in October, 1868, and the grading was about half finished before severe cold weather put a stop to operations." 116

The period 1866-1868 proved to be eventful for R. H. McBride, the Eldora Ledger, and the community which they served. When McBride issued his first journal in January of 1866 , the thought of steam cars to Eldora was merely an abstraction. Now the "Plug" had arrived, and Eldora was finally a "railroad town." Little more was heard of the Eldora, Nevada and Des Moines Railroad, and eventually that concern became one of the numerous "paper" roads of Iowa which were constructed only in the minds of their promoters. In a short while Eldora lost the prestige that came with being the headquarters of a railroad company, for the successor to the Iowa River Railways moved the corporate offices to Marshalltown. In the remaining thirty-two years of the Nineteenth Century, a series of line extensions lengthened Eldora's "Plug" to the Minnesota and Missouri borders, while corporate wars and financial instability kept painters in the Marshalltown shops busy changing the lettering on rolling stock. Following the Iowa River Railway came the Central Railroad Company of Iowa, Central Iowa Railway, and finally the Iowa Central Railway. In the Twentieth Century the road through Eldora became the mainline of the Minneapolis and St. Louis Railway. Now the tracks provide a main artery for the Chicago and North Western System.

R. H. McBride, in much the same fashion as other editors around the state, earnestly labored to bring adequate rail transportation to a burgeoning area. His efforts were less rewarded than some, more rewarded than others. Indeed, in

${ }^{115}$ Judge William Battin and F. A. Moscrip, Past and Present of Marshall County, Iowa (Indianapolis, B. F. Bowen and Company, 1912), I, pp. 201-202.

${ }_{116}^{16}$ History of Hardin County, Iowa, p. 508. 
$1868 \mathrm{McBride}$ declared that "the line will be lengthened north and south ... [and] . . w will dress up on the Eldora Line." ${ }^{117}$ Today a heavy volume of tonnage, bound to and from Minnesota and Missouri, moves through Eldora. The passing of every flanged wheel bears testimony to the prophecy and efforts of this Iowa editor.

${ }^{117}$ Eldora Ledger, June 27, 1868.

At 12 o'clock noon on August 25, 1972 a ceremony commemorating the fifty-second anniversary of Woman Suffrage was held in the autograph room of the Historical Building. The restored portrait of Annie Savery, a pioneer Iowa feminist, provided a handsome and appropriate backdrop for the reading of Governor Robert D. Ray's proclamation declaring August 26, 1972 Equal Rights Day in Iowa. Among the speakers at the ceremony was Kay Plymat, president of the Des Moines chapter of the National Organization of Women (NOW), who said she was glad that Iowa has ratified the Equal Rights Amendment to the Constitution. Louise Noun, author of Strong-Minded Women: The Emergence of the Woman-Suffrage Movement in Iowa, noted that Annie Savery is a forgotten woman and that the purpose of the ceremony was, in part, to pay tribute to her. Mrs. Savery was an active advocate of women's rights from 1868 until failing health in the eighties forced her to limit her activities. Visitors to the Historical Building can now view the portrait of Annie Savery on the third floor, west. 
Copyright of Annals of Iowa is the property of State of Iowa, by \& through the State Historical Society of Iowa and its content may not be copied or emailed to multiple sites or posted to a listserv without the copyright holder's express written permission. However, users may print, download, or email articles for individual use. 